\title{
Challenges and Opportunities in the Establishment of ASEAN Open Skies Policy
}

\author{
Dodik Setiawan Nur Heriyanto* dan Yaries Mahardika Putro** \\ DOI: https://doi.org/10.22304/pjih.v6n3.a3
}

Submitted: August 26, 2019 | Accepted: December 20, 2019

\begin{abstract}
Open skies policy is a concept of free market of airline industry. It eliminates single government's influence in regulation and management of aviation industry. As implemented by the ASEAN Single Aviation Market (ASEAN-SAM) per 2015, the open skies policy aims to increase regional connectivity and regional economic growth by permitting airline industries from each ASEAN member states to fly above the Southeast Asian region without any barriers or restrictions. This policy has raised pros and cons from each ASEAN member state. Indonesia and some other states are still reluctant to adopt the open skies policy. By entering into commercial agreement to open their airspace, each member states will challenge their state sovereignty over the airspace above a state's territory. This study argues that regional open skies policy provides greater economic advantages for the consumers of airline industry. However, this policy does not parallel to the basic principles of ASEAN. State sovereignty must be preserved in the liberalization that open skies represents. ASEAN Way, though inflexible, assigns member states with full sovereignty, which does not limit open skies policy implementation. This study, then, proposed legal framework through model of regional agreement to compromise between the state sovereignty principles and the regional open skies policy.
\end{abstract}

Keywords: ASEAN, Open Skies Policy, State Sovereignty

\section{Tantangan dan Peluang dalam Pembentukan Kebijakan Ruang Udara Terbuka ASEAN}

\begin{abstract}
Abstrak
Kebijakan Udara Terbuka adalah konsep pasar bebas untuk industri penerbangan. Kebijakan ini menghilangkan pengaruh pemerintah dalam mengatur dan mengelola industri penerbangan. Seperti yang diterapkan oleh Pasar Penerbangan Tunggal ASEAN (ASEANSAM) pada 2015, Kebijakan Udara Terbuka ditujukan untuk meningkatkan konektivitas regional dan ekonomi regional dengan mengizinkan industri penerbangan dari anggota ASEAN untuk terbang bebas di kawasan Asia tenggara tanpa hambatan. Kebijakan ini telah menimbulkan pro dan kontra dari masing-masing negara anggota ASEAN di mana Indonesia dan beberapa negara masih enggan untuk sepenuhnya mengadopsi Kebijakan Udara Terbuka. Dengan mengadakan perjanjian komersial untuk membuka wilayah udara
\end{abstract}

PADJADJARAN Journal of Law Volume 6 Number 3 Year 2019 [ISSN 2460-1543] [e-ISSN 2442-9325]

* Lecturer of the Department of International Law, the Faculty of Law, Universitas Islam Indonesia, Jl. Taman Siswa No.158 Yogyakarta, S.H., (Universitas Islam Indonesia), M.H. (Universitas Islam Indonesia), LL.M. (University of Debrecen), Ph.D (University of Debrecen), E-mail: dodiksetiawan@uii.ac.id.

** Student of the LLM Program, Faculty of Law, University of Debrecen and researcher at Base for International Law and ASEAN Legal Studies (BILALS). E-mail: yariespm@gmail.com. 
mereka, setiap negara anggota akan menyerahkan kedaulatan di wilayah udara mereka. Studi ini berpendapat bahwa Kebijakan Udara Terbuka regional memberikan keuntungan ekonomi khususnya bagi konsumen industri penerbangan. Namun, kebijakan ini tidak sejalan dengan prinsip dasar ASEAN. Selain itu, berkurangnya kedaulatan di wilayah udara demi liberalisasi akan merugikan negara. ASEAN Way, meskipun tidak fleksibel, memberikan kedaulatan penuh kepada negara anggota untuk menguasai wilayahnya sehingga tidak memberikan peluang sekecil apa pun untuk mengimplementasikan Kebijakan Udara Terbuka regional. Studi ini mengusulkan suatu kerangka hukum melalui model perjanjian untuk mencari titik temu antara prinsip kedaulatan negara dengan Kebijakan Udara Terbuka.

Kata kunci: ASEAN, Kebijakan Udara Terbuka, Kedaulatan Negara.

\section{A. Introduction}

The idea of state sovereignty over airspace has a long history. At the early stage, there had been academic and political debates over whether or not the skies should be free from being subjected to state's sovereignty. ${ }^{1}$ However, after the 1919 Paris Convention states consistently had asserted sovereign control over their airspaces. As stated in Article 1 of the 1944 Chicago Convention on Aviation, "The contracting states recognize that every state has complete and exclusive sovereignty over the airspace above its territory."2 This echoes the sovereignty declared in the 1919 Paris Convention. ${ }^{3}$ It is a fundamental premise that the relevant legal scheme of airspace operations is sovereign territory of state. Addressing the spatial extent of territorial sovereignty, Lachs notes the notion cuius est solum eius est usque ad coelum et ad sidera [inherited from Roman law, and was accepted by international law and adapted to its needs]. ${ }^{4}$ The phrase and its varying articulations essentially means "whoever owns the land owns it all the way to the sky and to the stars". ${ }^{5}$ The language, precisely, may not have been originated in Rome but the concept did. Currently, the application is a transparent articulation of air sovereignty that is recognized (but not created) in the 1919 Paris Convention and 1944 Chicago Convention, especially their respective first articles. ${ }^{6}$ Recently, the International Court of Justice (ICJ), in the settlement of the Military and

\footnotetext{
Paul Stephen Dempsey, Public International Air Law, Montreal: Mc. Gill University, 2008, p. 105.

Article 1 of the Convention on International Civil Aviation 1944

Article 1 of the Convention Relating to the Regulation of Aerial Navigation 1919

Manfred Lachs, The Law of Outer Space: An Experience In Contemporary Law-Making, The Netherland: Martinus Nijhoff Publisher, 2010, p. 40.

5 This rule means "Whose is the soil, his it is up to the sky," or in a simpler explanation "He who possesses the land possesses also that which is above it." Other elucidations are: "He who owns the soil owns everything above (and below) from heaven (to hell)," and "He who owns the land owns up to the sky."

$6 \quad$ J. L. Brierly, The Law of Nations: An Introduction to the International Law of Peace, 1st ed, Gloucestershire: Clarendon Press, 1928, pp. 91-92.
} 
Paramilitary Activities of Nicaragua Case (Nicaragua v. United States) ${ }^{7}$ and the Frontier Dispute case (Benin/Niger) has affirmed the sovereignty of airspace. ${ }^{8}$

In regard to sovereignty of airspace, as well as to maintain, develop and strengthen friendly relationship and cooperation among states, many states have agreed to establish open skies agreement. Open skies agreement is bilateral or multilateral agreement between or among states allowing air carriers to fly and to land in any airport of state-parties to the agreement. It contains mutual obligations to limit the authority of a single signatory state over commercial airline policies. ${ }^{9}$ It is less restrictive civil aviation regime ${ }^{10}$ and a signal of the establishment of a free market system in international civil aviation. ${ }^{11}$

By the end of the $20^{\text {th }}$ Century, there had been significant changes in airline regulation. The United States had begun pursuing open skies agreements in 1979 . By 1982, it had signed twenty-three bilateral air service agreements worldwide, mainly with smaller nations. Subsequently, in the 1990s they also have conducted agreements with European states bilaterally. A huge step was taken in 1993 when the Netherlands signed the first open skies agreement with the United States ${ }^{12}$. The agreement allows the American and Dutch airlines to penetrate into each other's markets, unrestricted capacity-and-frequency of all routes, and the greatest possible degree of freedom in setting fares. ${ }^{13}$

As an organization, which aims to develop its economic growth, ASEAN also endeavors to formulate an open skies policy. The effort reached its peak in 2009, when ASEAN member states agreed to talk on the issue. These and subsequent talks after have resulted in an agreement entitled The ASEAN Multilateral Agreement on Air Services and the ASEAN Multilateral Agreement on the Full Liberalization of Air Freight Services. The agreements were simultaneously approved on May 20, 2009, in Manila, the Philippines. The air transport agreements involve the ten-member Association of Southeast Asian Nations and have started to valid on January 1,2010 , as a part of the broader ASEAN Air Transport integration and Liberalization Plan.

In 2016, ASEAN began to operate the ASEAN Single Aviation Market (ASEANSAM), also known as the ASEAN Open Skies Agreement. It is intended to develop

\footnotetext{
Military and Paramilitary Activities in and Against Nicaragua: Nicaragua Vs United State, Judgment, International Court of Justice, 1986.

Frontier Dispute: Benin Vs Niger, Judgment, International Court of Justice, 2005.

I. H. Ph. Diederiks-Verschoor, An Introduction to Air Law, The Hague: Kluwer Law International, 1991, p. 50.

10 Adam L. Schless, "Open Skies: Loosening The Protectionist Grip on International Civil Aviation", Emory International Law Review, Volume 8, Issue 1, 1994, p. 447.

12 Agreement to Amend the Air Transport Agreement, as amended, and the Protocol Relating to the United States-Netherlands Air Transport Agreement of 1957, as amended 1992.

13 Daniel C. Hedlund, "Toward Open Skies: Liberalizing Trade in International Airline Services", Minnesota Journal of Global Trade, Volume 3, Issue 2, 1994, pp. 271-273.
}

$11 \quad$ ibid. p. 438. 
a unified and single market aviation of ASEAN members. ${ }^{14}$ The ASEAN Air Transport Working Group proposed the arrangement and the ASEAN Senior Transport Officials Meeting supported it. The ASEAN-SAM aims to strengthen the single market policy of the ASEAN Economic Community.

Liberalization of the ASEAN aviation markets in the ASEAN-SAM provides competitive advantages for both consumers, who enjoy the lowest fares, and the participating states, which are benefited with the increase of tourism and investment. ${ }^{15}$ It will automatically deregulate bilateral and multilateral air services agreed among the ASEAN member states. Unfortunately, not all ASEAN member states support the ASEAN-SAM. Up to now, Indonesia remains opposed to opening up its secondary cities. The Philippines also excludes Manila from the agreement. Lastly, Laos has not freed up Luang Prabang and the national capital Vientiane. ${ }^{16}$

Philosophically, open skies policy contradicts with the strict view of state sovereignty of airspace above its territory. ASEAN member states also recognize state sovereignty in absolute model. Some of them maintain to be restrictive and protectionist for the air trade policies. ${ }^{17}$ Their ASEAN way of regional policies that tends to use the full sovereignty model is the main barrier to agree on the regional Open Skies Policy. This study aims to elaborate advantages of the application of Open Skies Policy in ASEAN regional level. It also analyzes the concept of state sovereignty and its correlation to the benefits of open regional skies policy.

There have been limited numbers of studies on Indonesian air space law. Minimum references and studies on the topic is the main cause of researchers' reluctance to analyze problems of air space law. Study of the ASEAN Open Skies Policy is the novelty of this study since it does not only take into consideration the enormous advantages of the Open Skies Policy within the ASEAN region but, rather, this study analyzes its correlation to the sovereignty of the ASEAN member states.

The study employed normative research method. It is an interpretative scheme that overall framework of categories, assumptions, and concerns operate both set up and demarcate the very meaning, scope, and purpose of this study. ${ }^{18}$ The method enables the study to analyze the concept of state sovereignty under

14 Winnie Yoh, (et. al.), "ASEAN on Track for Open Skies Policy", The Jakarta Post, 2015 http://www.thejakartapost.com/news/2015/03/19/asean-track-open-skies-policy.html accessed on February 2019.

15 Chuck Y. Gee, "Aviation and Tourism: The Travelling Public", Transportation Law Journal, Volume 20, Issue 1, 1991, pp. 2-3.

16 Jennifer Meszaros, “Protectionism Still Winning as Liberalization Stalls", https://www.ainonline.com/aviationnews/air-transport/2016-02-15/protectionism-still-winning-liberalization-stalls accessed on February, 2019.

17 H. A. Wassenbergh, "The Application of International Trade Principles to Air Transport", Air and Space Law, Volume 12, Issue 2, 1987, p. 88.

18 Michael Salter \& Julie Mason, Writing Law Dissertation: An Introduction and Guide to the Conduct of Legal Research, Harlow: Pearson, 2007, pp. 44-45 
international law: to be precise, whether or not state sovereignty can be respected in the current development of Open Skies Policy.

The sovereignty principle, in fact, has a broad scope, sometimes with different applications. To analyze application of state sovereignty principle on the Open Skies Policy, this study used two important approaches. The first is comparative approach to analyze the advantages of open skies policy. This study compared the existing application of open skies policies. The approach resulted comprehensive description of advantages of Open Skies Policy. The second is conceptual approach to address the development of open skies policy. The conceptual enables the study to gather any relevant model of open skies agreements that is suitable for ASEAN.

\section{B. Initiation and Development of ASEAN Open Skies}

Air transport is an important sector in Southeast Asia that contributes to the economic development of the ASEAN member states. Based on the objective of the ASEAN Economic Community, a regional economic integration plan by the end of 2015, the ASEAN member states aim to implement a liberalization policy of regional air services: the ASEAN Single Aviation Market (ASAM). ASAM is considered an important milestone that will increase connectivity, economic growth, and social welfare of the region ${ }^{19}$. The need of a coherent system of air travel infrastructure and the increasing demand of low-cost travel are the main triggers for the adoption of the Opens Skies Policy by ASEAN. ${ }^{20}$ The ASAM consists of a number distinct policy aspect (such as capacity deregulation and removal of price controls) that should lead to less regulation in airline services. ${ }^{21}$ ASEAN's plan of air transport liberalization had been discussed since the early 1995 during the fifth summit of ASEAN Leaders in Bangkok. Later, this topic was brought into the ASEAN Bali Declaration Concord II at the $9^{\text {th }}$ ASEAN Summit in October 2003, in Bali, Indonesia. 22 As part of the commitment to establish the idea of an Open Skies Policy in Southeast Asia, the ASEAN State Members have agreed to establish multilateral agreement on air liberalization. Today, there are three main aviation agreements that underpin the ASAM as follows. ${ }^{23}$

\section{The Multilateral Agreement on Air Service (MAAS)}

The agreement was inked by ASEAN countries on May 20, 2009, in Manila. It is the first multilateral agreement, which contained relaxation of third/fourth, and fifth air freedom rights among ASEAN capital cities.

\footnotetext{
19 Hanaoka, Shinya (et. al), "Low-cost Carriers Versus Full service Carriers in ASEAN: The Impact of Liberalization Policy on Competition", Journal of Air Transport Management, Volume 40, Issue 1, 2014, pp. 96-105.

20 Nurhendiarni, Sri (et.al.), "The Effect of ASEAN Open Skies Policy 2015 Upon Opportunities for Low-Cost Carriers in Indonesia - A Case Study of PT. Citilink", The South East Asian Journal of Management SEAM, Volume 9, Issue 1, 2015, pp. 34-51.

21 Forstyh, Peter, (et.al.), "Open Skies in ASEAN", Journal of Air Transport Management, Volume 12, Issue 3, 2006, pp. 143-152.

22 Mahmud, Fachri, ASEAN Open Sky dan Tantangan Bagi Indonesia, Jakarta: PT. Mahmud Yunus Wadzuriyah, 2012, p. 91.

23 Towards ASEAN Open Sky, Malaysia: MIDF Research, 2014, p. 5
} 


\section{The Multilateral Agreement of Full Liberalization of Air Freight Services (MAFLAFS)}

This agreement was ratified on December 10, 2009, to ensure a more efficient and competitive international air freight service, promoting regional economic growth. The agreement entails unlimited third/fourth and fifth air freedom rights among all international airports for airfreight service. Indonesia opted out over protection of its air cargo companies against competition from other regional freight companies.

\section{The Multilateral Agreement for Full Liberalization of Passenger Air Services (MAFLPAS)}

This agreement was inked between by member states on November 10, 2010. Similar to MAFLAFS, the MAFLPAS addresses passenger air services and adopts the third/fourth and fifth air freedom rights among all ASEAN secondary international airports. MAFLPAS supplements MAAS to cover access points in the ASEAN region other than those of the capital cities. Fewer member states accepted this agreement. Indonesia, Laos, and Cambodia opted out. The Philippines signed MAFLPAS to allow entry into its secondary cities, but retained restricted access to the Ninoy Aquino International Airport remains restricted.

Mostly, the sentiments amongst each ASEAN members towards a more liberalized market are mixed due to stakes in their respective aviation industries. Impediments also emerge from the establishments of the ASAM concept. The fundamental impediments arise from the enforcement of ASAM, as ASAM is less ambitious compared to the Single European Sky and Trans-Tasman Single Aviation Market policies. ASAM only enforces the third, fourth and fifth Air Freedom Rights (AFR) while outside ASEAN airlines are not allowed to connect between two domestic points within the region. The concept or idea of Open Skies Policy would implement the all of AFR. ${ }^{24}$

\section{The Advantages of the Establishment of ASEAN Open Skies}

ASEAN aims to integrate the various national aviation markets into an ASEAN Single Aviation Market by the end of $2015 .{ }^{25}$ The drive to create ASAM began in 1996 with a memorandum on air services policy and it has yielded two multilateral agreements in 2009 and 2011, which have redefined the $3^{\text {rd }}, 4^{\text {th }}$, and $5^{\text {th }}$ freedom rights in the region as well as restrictions on ownership. Integrating ASEAN economies is very challenging and requires relentless efforts by its members. This is further complicated by ASEAN's expansive and geographically fragmented land area of $4,46 \mathrm{~m} \mathrm{Km}^{2}$.

24 Tan, Alan Khee-Jin, "The ASEAN Multilateral Agreement on Air Services: En Route to Open Skies?" Journal of Air Transport Management, Volume 16, Issue 6, 2010, pp. 289-294.

25 Lee, Dexter, The European and Southeast Asian Single Aviation Markets, Singapore: European Union Center in Singapore, 2015, p. 9. 
One of the fastest traffic-growth areas in the world today is the Asia-Pacific Region. ${ }^{26}$ The ASEAN functions as a regional bloc much like the European Union (EU) and works to facilitate collaboration on tourism, trade, and economic growth. ${ }^{27}$ The ASAM is a comprehensive policy adopted by the region with the goal of developing a single, integrated aviation market with fully liberalized air travel among its member nations. Although air traffic growth in the Asia-Pacific region had already grown significant for a number of years, the adoption of the MAAS and MAFLPAS have accelerated the increase in market share for low cost carriers (LCC), and both international and domestic travel in the ASEAN market have more than doubled between 2005 and 2012. ${ }^{28}$

The traffic growth experienced by liberalized markets produces economic growth and generates jobs. The benefits of air travel liberalization further are illustrated by the substantial and undeniably positive impact of deregulation on other industries. ${ }^{29}$ Across a variety of sectors, liberalization benefits consumers by lowering prices, providing a wider array of options, and improving quality of services. The benefits made available to the commercial air services could be extended to the commercial passenger segment further multiplying the economic effects of the liberalization. This should benefit the LCC in ASEAN while promoting a more conducive landscape that could pave the way for new players and/or provide the opportunity for troubled or ailing airlines to reinvigorate their existing businesses. ${ }^{30}$

Fully liberalized air travel among its member states would enable ASEAN to benefit from the growth in the air travel around the world directly. This will also be freeing up tourism, trade investment, and services flow among member states. ${ }^{31}$ The ASEAN Open Sky Policy brings several primary or secondary benefits. The primary benefits include the following.

\section{Benefits for ASEAN's Tourism Sector.}

The users of air transport will gain or lose depending on the implementation of policy options. If implementing an option results in lower fares, the travelers gain a benefit. If an option results in lower frequency of service, the travelers will face a cost. Mainly, travelers will gain a positive benefit from lower prices, insofar as other factors such as quality remain constant. They will also gain if the product mix

26 INTERVISTAS, The Economic Impacts of Air Service Liberalization 2015,http://www.intervistas.com/wpcontent/uploads/2015/07/The_Economic_Impacts_of_Air_Liberalizatio n_2015.pdf_accesed on April 2019.

27 Lykotrafiti, Antigoni, "Liberalisation of International Civil Aviation: Charting the Legal Flightpath", Transport Policy, Volume 43, Issue 1, 2015, pp. 85-88.

28 Cline, Hannah E, "Hijacking Open Skies: The Line Between Tough Competition and Unfair Advantage in the International Aviation Market", Journal of Air Law and Commerce, Volume 81, Issue 3, 2016, pp. 529-559.

29 Smyth, Mark \& Pearce, Brian, Airline Liberalisation: IATA Economics Briefing No. 7, Montreal: International Air Transport Association, 2007, p. 17.

30 ibid.

31 Wee, Datuk Dr. Victor, Impact of Air Services Liberalisation on Growth of Tourism in Asia, Proceeding $6^{\text {th }}$ UNWTO International Meeting on Silk Road Tourism, Gansu, 1-3 August 2013, p. 17. 
is improved, and choice is widened. For example, when lower cost-based fares become available, some of the benefits accrue to leisure travelers, who are travelling for their own reasons, such as vacation. ${ }^{32}$ In 2012, the tourism sector contributed USD256 billion of $11 \%$ of ASEAN's Gross Domestic Product [hereinafter, 'GDP'] with USD92 billion revenues being generated by international tourists. ${ }^{33}$ The tourism industry continues to experience healthy growth. The total contribution of travel and tourism to GDP, as reported by the World Travel \& Tourism Council, was $\$ 301.1$ billion in $2016 .{ }^{34}$ ASEAN has emerged as the fifth most visited region in the world. Tourism in Southeast Asia in 2016 contributed $11.8 \%$ to GDP, which was forecast to rise to $12.2 \%$ in $2017 .{ }^{35}$

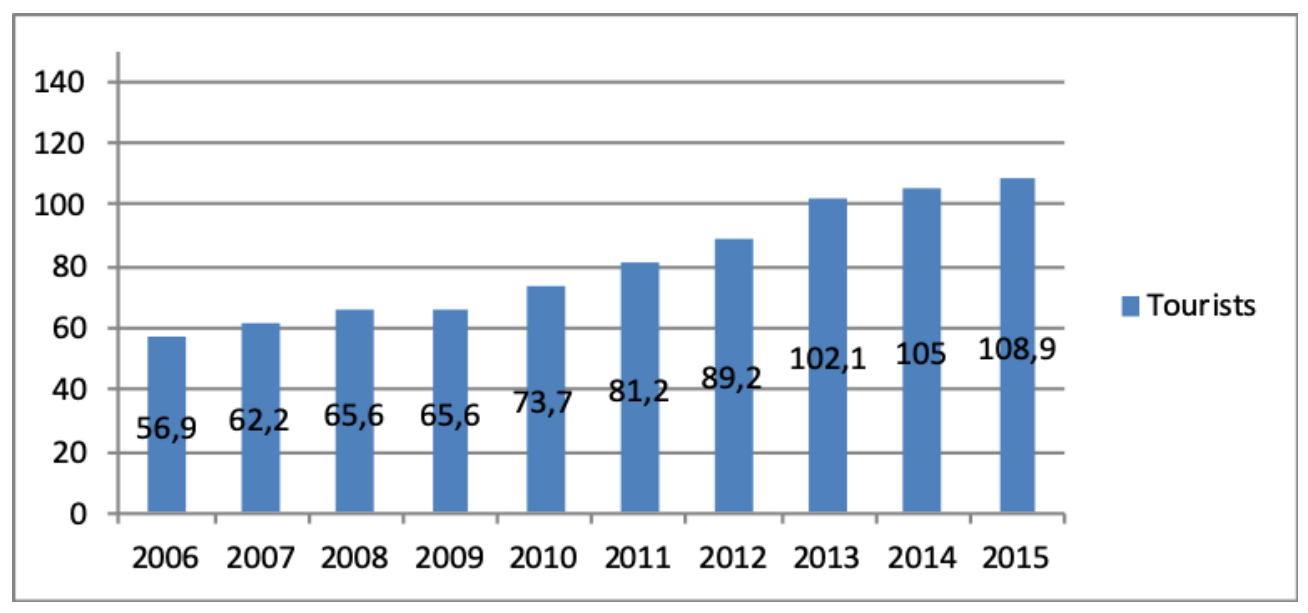

Source: ASEAN.org

Table 4.1. International Tourists Visit ASEAN 2006-2015

\section{Benefits to airlines and other producers}

Policy options can affect airline profits. Negatively, reducing revenues can reduce profits unless offset by reduced costs. Policy options can also reduce costs for the airline, and all other things being equal, would deliver a benefit to them. Competition tends to impose a cost on firms, since it forces prices, and thus profits, down. This will be mitigated to the extent that the firm is able to reduce costs through greater efficiency. If efficiency is enhanced, the gain to travelers from the lower prices will be less than the reduction in profits to the airline. ${ }^{36}$

\footnotetext{
32 Forsyth, Peter, Preparing ASEAN for Open Sky, AADCP Regional Economic Policy Support Facility Research Project 02/008, Australia: Monash International Pty Ltd, 2004, p. 90.

MIDF, op.cit, p. 90

World Travel \& Tourism Council, Travel \& Tourism Economic Impact 2017 South East Asia, 2017.

ASEAN Secretariat, ASEAN Tourism Marketing Strategy 2017-2020, Jakarta, 2017, p. 17.

Forsyth, op.cit, p. 91.
} 
From the eleven countries in Southeast Asia, there were nearly 39.000 flights offering 6.3 million seats per week in 2013. By comparison, in Europe west of Russia, which has roughly the same population and physical extent, there were nearly 17 million seats per week. ${ }^{37}$ However, Southeast Asia has experienced robust growth, which has increased the region's power in the global airline industry; seat capacity grew nearly threefold between 1998 and 2012, with expansion concentrated in the most recent years. The strong correlation between economic development and the relative size of the aviation industry explains much of Southeast Asia's growth of airline capacity. The pattern is clear; with higher levels of economic development, air transportation becomes more significant. ${ }^{38} \mathrm{We}$ believe that established airlines are key beneficiaries of the ASEAN Open Skies Policy especially for the LCCs. The region has the highest LCC penetration rate in the world and is home to some world-renowned LCCs such as Air Asia, Lion Air and Cebu Pacific. ${ }^{39}$ Fueling the growth is the growing disposable income group, which propagates demand for leisure travel and intra-ASEAN trades and business activities.

\section{Air Freight liberalization fosters growth in trades.}

We foresee ample growth in trade activities as better air travel services enhances people-to-people contacts, which could also create new trade opportunities. The competitiveness of selected manufactured goods would also be reliant on the capability of transportation services to enable the free movement of goods. The study estimated that Open Skies Policy will account for around 2.9 trillion Rupiah (\$2.7BN) in additional direct GDP and an additional 16,000 direct jobs in 2025.

In addition to these primary impacts, the ASEAN Open Skies Policy also brings several secondary effects. The main secondary benefits come from the economic gain's countries make from tourism expenditures. Lower airfares and better services will stimulate inbound tourism and increase expenditures. Outbound tourism will also increase for some countries, but some countries may realize a net loss from this effect. There is a range of other impacts, which will create benefits or costs, depending on the circumstances. These include impact on government revenue, currency exchange, employment, economic risk, and improvement to business communications within ASEAN. ${ }^{40}$

\section{Learning from the Application of other Regional Open Skies Policy}

To provide a comprehensive understanding of the costs and benefits of the establishment of regional open skies agreement, ASEAN could consider to render the practice of open sky agreements under the SES (Single European Sky), the

\footnotetext{
37 Bowen, John T, "Now Everyone Can Fly? Scheduled Airline Services to Secondary Cities in Southeast Asia", Journal of Air Transport Management, Volume 53, Issue 1, 2016, pp. 94-104. 
TTSAM (Trans-Tasman Single Aviation Market), ${ }^{41}$ and the EU-US OAA (Open Aviation Area). They represent highest degree of liberalization with the relaxation of all nine AFRs. The three joint open sky practices provide greater advantages for each party and enlarge the aviation market quality at the regional level.

\section{Single European Sky}

In the late 1990s, high level of European air-traffic development, combined with the liberalization of the air transport industry within the community raised concerns about the ability of the air traffic management (ATM) sector to meet the projected capacity requirements needed to support increasing air traffic demand. The European Economic and Social Committee had actively supported the Single European Sky, adopting options in 2002, 2009 and 2011, and exerting a growing influence on EU decision-making. ${ }^{42}$ The main goal of the SES is to reform the architecture of the European air-traffic control to meet future capacity and safety needs, ${ }^{43}$ to enhance the overall efficiency of general air traffic (GAT) in Europe, to minimize delays and to establish a harmonized regulatory framework. ${ }^{44}$

The background of the establishment of SES was influenced by several conditions that happened in European Aviation sector. As more efficient and effective transportation, air transport plays a crucial role in Europe's economy. Nevertheless, the industry was in crisis, with the current economic conditions contributing to airline mergers, bankruptcies, and job cuts. Additionally, the Air Traffic Management sector was over capacity and five times less cost-efficient than others were. In addition, air traffic management in Europe was fragmented and dominated by National entities. There is the possibility of monopoly in this sector. Delays and cancellations also contributed to the European Commission's attempt to implement a Single Open Sky Policy. The EU estimates that Europe's fragmented airspace was costing EUR 4 billion a year, including 19.4 million minutes of flight delays. ${ }^{45}$ Through the reasons above, the European Commission believed that those problematics could be tackled by establishing a Single European Open Skies Policy.

In 2004, the European Commission proposed a package of measures covering everything from passenger safety and cost efficiency to environmental protection, technical standards and traffic flow management, commonly known as Single European Sky I (SES I). This legislative package contains four elements. It contains a regulation laying down the framework for the creation of the Single European Sky

\footnotetext{
41 Trans-Tasman Single Aviation Market is the Liberalisation in aviation sector between Australia and New Zealand.

42 ibid.

43 Hartman and Boscoianu, "Single European Sky The Transformation of The Aviation Industry Based on The Dynamic Capabilities", Incas Bulletin, Volume 7, Issue 1, 2015, p. 98.

44 Eurocontrol, op.cit, p. 7.

45 Eurocontrol, All-Causes Delay to Air Transport in Europe, Brussels: The European Commission, 2017, p.1.
} 
or the Framework regulation, ${ }^{46}$ a regulation laying down common requirements for the provision of air navigation services, ${ }^{47}$ a regulation on the organization and use of airspace in the Single European Sky, ${ }^{48}$ and a regulation on the interoperability of the European Air Traffic Management network. ${ }^{49}$ Creating a single European sky also required the collective management of airspace. All players in European air traffic management (ATM) including national authorities, civil and military authorities, airspace users, air navigation-service providers, and airport began to work with the European Commission on this exercise. ${ }^{50}$ Over the five years following the launch of the SES I, the situation changed to a certain extent. While capacity still was a cause for concern, greater emphasis began to be placed on aviation's impact on the environment and the fuel crisis made airlines focus on cost efficiency.

In 2007, various assessments of the results obtained after three ears of implementation of the first package confirmed the need to go further and to set up a second package if a real Single European Sky was to be achieved. A revision of this package was proposed in 2009, with the objectives of tackling the challenge of substantial growth in air traffic, increasing safety, and reducing costs, delays and the impact of air traffic on the environment, the European Commission named this proposal with Single European Sky II (SES II). ${ }^{51}$ The SES II package was built on four policy pillars, the first pillar is a legislative proposal for a "more sustainable and performing aviation" industry (performance), the second pillar is about technologySESAR (Single European Sky ATM Research), the third pillar concern is Safety-EASA (European Aviation Safety Agency), and the fourth pillar is Airports dimension. ${ }^{52}$ Nevertheless, in the process of implementation of second legislative package was not implemented as proposed.

Because of the impaired implementation, at the end of 2013, a new package of measures was submitted, a Single European Sky II Plus (SES II+). The European Commission approved this new legislative package on March 11, 2014, updating SES's founding regulations and amending the rules governing EASA. ${ }^{53}$ The main updates concerned improving safety and surveillance, performance objectives,

46 Regulation (EC) Number 549 Year 2004 of the European Parliament and of the Council of 10 March 2004 laying down the framework for the creation of the Single European sky, p. 1.

47 Regulation (EC) Number 550 Year 2004 of the European Parliament and of the Council of 10 March 2004 on the provision of air navigation services in the Single European Sky, p. 10.

48 Regulation (EC) Number 551 Year 2004 of the European Parliament and of the Council of 10 March 2004 on the organisation and use of airspace in the Single European sky, p. 20.

49 Regulation (EC) Number 552 Year 2004 of The European Parliament and of the Council of 10 March 2004 on the Interoperability of The European Air Traffic Management Network, p. 26.

50 Eurocontrol, The Single Europeans Sky Fact Sheet, Brussels: European Commission, 2011, p.1.

51 Ariane Debyser, Single European Sky, Brussels: European Parliamentary Research Service, 2015,p. 4.

52 op.cit, pp. 3-4.

53 Daniel Stanescu, "Single European Sky-The Solution For An Air Traffic Management Adapted To The Challenges of This Century", Review of the Air Force Academy, Volume 33, Issue 1,2017, p. 141 
support services, passengers, greater flexibility to allow industrial partnerships within FABs, and enhanced network management. ${ }^{54}$

\section{Trans-Tasman Single Aviation Market}

Air transport across the Tasman Sea has been regulated by an agreement between Australia and New Zealand made in $1961 .{ }^{55}$ In 1992, the two states concluded a Memorandum of Understanding (MOU), which lifted capacity restrictions across the Tasman Sea, introduced multiple designation and a double disapproval tariff regime, and set out a phased liberalization towards full trans-Tasman market access and greater beyond rights by 1994 . This MOU also contained a commitment to consult on the subsequent full exchange of beyond rights and cabotage rights, but Australia withdrew its commitment in 1994. In 1996, the two States succeeded in signing the Single Aviation Market (SAM) arrangements, which was incorporated into the CER (Closer Economic Relation) Protocol. ${ }^{56}$

In 2000, the states concluded an "Open Skies" agreement, which was officially signed in 2002. It allows the Seventh Freedom right for all-cargo services. This agreement allows Australian and New Zealand airlines to operate across the Tasman Sea and beyond to third countries without restrictions. The Trans-Tasman market is one of the most diverse and competitive markets with 11 passenger airlines and 4 cargo airlines offering services between Australia and New Zealand. ${ }^{57}$ In 2004, there were over 4.6 million passengers in the market, up from the nearly 3.3 million passengers in 2000, the year the "Single Aviation Market" between Australia and New Zealand was first fully implemented. ${ }^{58}$

\section{E. EU-US Open Aviation Area}

On April 30, 2007, the EU and US leaders signed the Open Skies Agreement at a summit in Washington. It came into force on March 30, 2008, ${ }^{59}$ and superseded the individual EU countries Open Sky Agreements that many EU countries previously had with the US, commencing with the Netherlands in 1992. In May 2008, second stage negotiations were launched with the aim of achieving an Open Aviation Area (OAA) by in the middle of $2010,{ }^{60}$ which would have considerable implications for

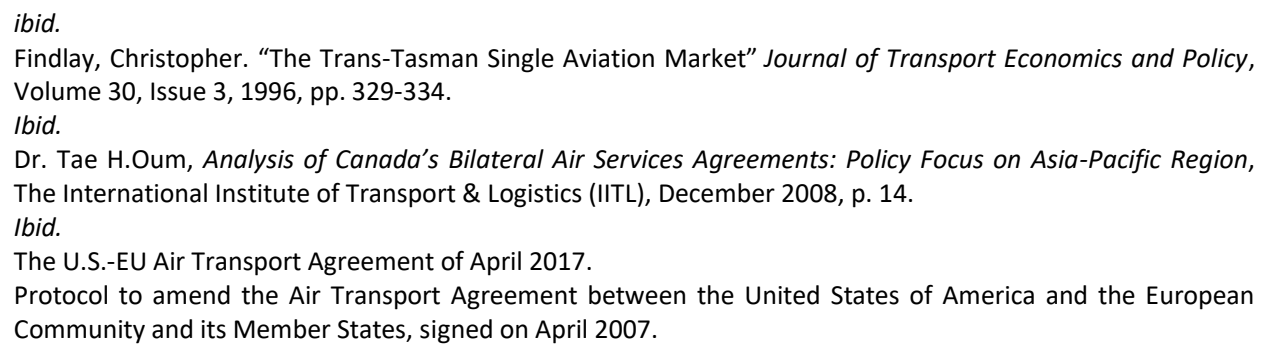


factor mobility and airline ownership if it is achieved. ${ }^{61}$ The Open Aviation Area concept is intended to deliver full market access, taking the form of extending full freedoms of the air to both parties, removing restrictions on investment by foreign owners, and allowing other activities such as wet leasing without restrictions. An OAA is intended therefore to provide a holistic framework that goes beyond the basic Open Sky model. ${ }^{62}$

The new agreement between the EU and the US provided several new aspects that had never been explored by either party. The new agreement contains major provisions, such as Open Skies between the US and the EU and all its 27 member states, broader entry into cooperative marketing arrangement for code sharing, franchising and leasing, for EU carriers the ability to route flights between any EU member state and the US without touching the home country's community carriers. ${ }^{63}$ Press reports and public statements by EU representatives estimate the value of the agreements at approximately $\$ 12$ billion annually in economic benefit to the translantic airline and related industries. ${ }^{64}$ The agreement is also expected to add 80.000 new jobs.

The various Open Skies agreements above have been running a long before the ASEAN Open Skies Policy entry into force. Each of these agreements mandated the importance of safety, security and the environment. Indeed, the ASAM is undeveloped compared to that of the SES, TTSAM and EU-US OAA policies. Those agreements have fully implemented the all nine AFRs instead of three AFRs that are implemented in ASAM. Furthermore, the member state parties to the SES, TTSAM and EU-US OAA fully cooperate to achieve the goals of those agreements. Nevertheless, ASAM as a new Single Aviation Market in the International community has the ambition to create a more innovative Single Aviation Market on their region. By considering the advantages to ASEAN member states in the ASAM region, it has proven that ASAM will transform into a new ambition in aviation sector.

\section{F. Sovereignty of ASEAN Member States as the Challenge for the Implementation of ASEAN Open Skies Policy}

\section{The Principle of Air Sovereignty}

As a fundamental principle under international law, ${ }^{65}$ state sovereignty should be considered in the framework of open sky policies. Globalization and economic

\footnotetext{
61 Pitfield, D.E, "The Assessment of The EU-US Open Skies Agreement: The Counterfactual and Other Difficulties", Journal of ir Transport Management, Volume 15, Issue 6, 2009, pp. 308-314.

62 Booz Allen Hamilton, The Economic Impacts of an Open Aviation Area between the EU and the US Final Report, London: Booz Allen Hamilton Ltd, 2007, p. 14.

63 Eugene Alford, The Impact of The 2007 U.S.-EU Open Skies Air Transport Agreement, 2007, Washington: U.S Department of Commerce, pp. 2-3.

64 Brattle Group, The Economic Impact of an EU -US Open Aviation Area, London: The Brattle Group Ltd, 2002, p. v.

65 Krasner, Sovereignty: Organized Hypocrisy, Princeton: Princeton University Press, 1999, p. 36.
} 
development raise dynamic notions on state sovereignty ${ }^{66}$ as well as in the utilization of airspace by states and aircraft corporations.

The concept of airspace sovereignty basically refers to the exclusive competence of a state to exercise its legislative, administrative and judicial powers within its national airspace. The original concept asserted the absolute notion of airspace sovereignty. Then, in early nineteenth century, most European states, through the Paris Convention, agreed to promote the right of innocent passage, subject to certain limitations. ${ }^{67}$ The Pan American Convention on Commercial Aviation furthered the adoption the limited right of innocent passage through the national airspace. ${ }^{68}$ The Chicago Convention, however, had a different model in its provisions: it does not provide the right of innocent passage but rather the article 6 supports the opportunity of international air service to schedule an operation with the special permission or other authorization of the contracting state. ${ }^{69}$ Moreover, the International Air Services Transit Agreement that was signed in 1944, gave to the airlines of the signatories overflight rights and the right to land in the territory of other contracting States for non-traffic purposes such as refueling. ${ }^{70}$

From this regulatory development, we can conclude that as part of customary international law, state sovereignty in airspace is undisputed. ${ }^{71}$ However, the increasing demand to liberalize states' airspace in order to improve competitiveness in air sector has become the key factor in the initiation of open skies policies. Such initiation indeed should be based on bilateral or multilateral agreement as a form of consent to gain access to a foreign state's airspace by aircraft for international commerce. ${ }^{72}$ The trend to liberalize the aviation market started in the USA in 1978. Based on a multilateral treaty to enforce the internal market, any European Union airlines can operate over other member states'

66 Abram Chayes and Antonia H Chayes, The New Sovereignty: Compliance with International Regulatory Agreements, Cambridge: Harvard University Press, 1995, p.26.

67 John Cobb Cooper, "The Air Navigation Conference, Paris 1910", Journal of Air Law and Commercial, Volume I19, Issue 2, 1952, p. 105.

68 The Pan American Convention on Commercial Aviation 1928, This convention also regulates the limited right of innocent passage. Article 4 of this Convention stated that "Each contracting state undertakes in time of peace to accord freedom of innocent passage above its territory to the private aircraft of the other contracting states, provided that the conditions laid down in the present convention are observed."

69 Article 6 Convention on International Civil Aviation, 1944.

70 Drafter of this Convention were the same person with the drafter of the Convention on International Civil Aviation, International Air Services Transit Agreement, signed at Chicago on December 1944.

71 William J. Hughes, "Aerial Intrusions by Civil Airliner and the Use of Force", Journal of Air and Commerce, 1980, p. 595

72 Myres S. McDougal, (et. al)., Law and Public Order in Space, Yale: Yale University Press, 1963, p. 268. 
territory even for domestic routes. ${ }^{73}$ Since then, open skies agreements have largely been established in the wake of the liberalization of the aviation market.

Growing existence of open skies agreements, however, do not lead to the abolition of state sovereignty. It means that a state unilaterally, for domestic air transport, bilaterally or multilaterally, for international air transport, adopts a commercial regime based upon a maximum of free market forces and a minimum of (inter) governmental intervention. ${ }^{74}$ Moreover, the role of state sovereignty still exists to protect states from the interferences from foreign governments. International obligations in the open skies agreements are merely to achieve the goal of mutual advantages in the side of economic liberation in the aviation market. It cannot be used some way to intervene in the domestic affairs of another state.

\section{G. Model for Regional Open Skies Agreement in ASEAN}

Previous analysis of state sovereignty as the greatest challenge to liberalization in the civil aviation sector leads to the conclusion that open skies policy on a regional level will increase mutual advantages for not only the industry but also states and their populations. Moreover, Hedlund (1994) noted that the classic open skies bilateral system is incapable of supporting the continued expansion and globalization of the international air transport industry and must be replaced by a multilateral regime. $^{75}$ Member states of ASEAN should consider to the establishment of a binding multilateral agreement to promote increased tourism and trade, to increase productivity, and to encourage high-quality job opportunities and economic growth at the regional level. Regional open skies policy will also offer a more competitive air transport market by reducing air transport costs. ${ }^{76}$ This supports to the ASEAN's single market policy of the free movement of goods, services, investment, capital, and skilled labor.

The ASEAN way may challenge the creation of an ASEAN open skies agreement. ${ }^{77}$ However, the challenging shared values could be reconciled with the current demands to liberalize the air transport. This study proposes the ideal model for ASEAN Open Skies Agreement. This model shall include important key provisions, such as: free market competition, price determination, establishment of regional monitoring and reporting body, dispute settlement and consultation, safety and security, and comity and reciprocity.

\section{Free Market Competition}

73 Chrystel Erotokritou, "Sovereignty Over Airspace: International Law, Current Challenges, and Future Developments for Global Aviation", Inquiries Journal of Social Science, Arts, and Humanities Volume 4, Issue 5, 2012, p. 40.

74 Peter P. C. Haanappel, The Law and Policy of Air Space and Outer Space: A Comparative Approach, The Hague: Kluwer Law International, 2003, p. 4.

75 Hedlund, op.cit, p. 259.

76 Clifford Winston and Jia Yan, "Open Skies: Estimating Travelers Benefits From Free Trade in Airline Services", American Economic Journal: Economic Policy, Volume 7, Issue 2, 2015, pp-410-414.

77 Amitav Acharya, "Culture, Security, Multilateralism: The ASEAN Way and Regional Order", Contemporary Security Policy, Volume 19, Issue 1, 2007, pp. 56-58. 
Free markets minimize government intervention at all levels in international aviation markets. The pricing policy shall determine by the open market and by consumers. Free market policy is more desirable because they cheaply, effectively, and constantly provide incentives that force producers to produce efficiently to satisfy consumers. ${ }^{78}$ On this basis, ASEAN Open Skies shall undertake to eliminate controls on capacity, routes, frequency, and price. ${ }^{79}$ It also shall guarantee the promotion of freedoms of the air, which consist of the following nine freedoms. ${ }^{80}$

a. First Freedom is the right to fly over another nation's territory without landing.

b. Second Freedom is the right to land in a foreign country for non-traffic reasons, such as maintenance or refueling, without picking up or setting down revenue traffic.

c. Third Freedom is the right to carry people (or cargo) from the airline's own country to the other country.

d. Fourth Freedom is the right to carry people (or cargo) from the other country to the airline's own country.

e. Fifth Freedom is the right to carry traffic between two foreign countries with services starting or ending in the airline's own country (also known as beyond rights).

f. Sixth Freedom is the right to carry traffic between two countries via the airline's own country.

g. Seventh Freedom is the right to carry traffic between two foreign countries on a service that does not involve the airline's own country.

h. Eighth Freedom is the right to carry traffic between two points within a foreign country (i.e., domestic traffic) as an extension of a service starting or ending in the airline's own country (also known as tag- on or fill-up cabotage).

i. Ninth Freedom is the right to carry traffic between two points within a foreign country with no requirement to start or end the service in the airline's own country (also known as pure or standalone cabotage).

\section{Pricing determination}

To avoid predatory or excessive pricing ${ }^{81}$, airlines shall have the freedom to set their fares without restriction. ASEAN member states are not supposed to intervene the pricing determination unless in the case of infringement of fair competition norms.

\footnotetext{
78 Michael E. Levine, "Airline Competititon in Deregulated Markets: Theory, Firm Strategy, and Public Policy", Yale Journal on Regulation, Volume 4, Issue 2, 1987, p. 393

79 US Department of State, "Open Skies Agreement Highlights", https://20012009.state.gov/e/eeb/rls/fs/2006/208.htm\# accessed on March, 2019.

80 ICAO, "Manual on the Regulation of International Air Transport", https://www.icao.int/Meetings/a39/Documents/Provisional_Doc_9626.pdf accessed on March, 2019.

81 Rigas Doganis, The Airline Business, London: Routledge, 2006, p. 73.
} 


\section{Establishment of regional monitoring and reporting body}

ASEAN shall also establish or empower the existing body to check the operation of ASEAN Open Skies Agreement regularly. This body may also provide certification for service quality and safety standard to ensure that all airlines operated within the member states meet the minimum standard of service and safety. This body has the power to propose effective sanctions for non-compliance.

\section{Safety and Security}

In addition to safety standards, the ASEAN Open Skies Agreement also should apply the international standards to prevent the act of terrorism, sabotage, hijackings, and other criminal acts that endanger the regional air security.

\section{Exchange of Information and Experiences}

In the spirit to improving the quality, maintaining the commitment, and promoting the aviation safety, each of the aviation industries in ASEAN shall committed exchange of information and experiences mechanism them in order to identify information and experience that can be exchanged between them to enhance risk reduction activities in the area of aviation safety. ${ }^{82}$

\section{Comity and Reciprocity}

Consistent with the ASEAN values, the operations of ASEAN Open Skies Agreement shall also render to the principle of comity and reciprocity. Reciprocity is the element of the principle that creates a relationship based on comity, as states are prepared to recognize the authority of other states within what is naturally a sovereign field on the basis that their partners are willing to do the same. ${ }^{83}$

\section{Settlement of Disputes}

This provision provides a passage for arbitration and final resolution should the issue in "consultations" not be resolved with talks between the countries. ${ }^{84}$ The establishment of this body must be associated with the values of independence, impartiality, transparency, adversarial principle, effectiveness, legality, liberty, principle of representation and fairness. ${ }^{85}$ In order to strengthen the decision, the formulation of National Enforcement Bodies shall take into account. ${ }^{86}$ This authority will play vital role in ensuring that the party have implemented the decision.

Subsequently, to drawing attention and interest from all stakeholders, airlines, and governments, the model of ASEAN Open Skies policy should guarantee that each ASEAN's airline is able to show their capacity and best reputation on aviation industry. The concept of subsidy to the airlines industries can be an ideal

\footnotetext{
International Civil Aviation Organization (ICAO), State of Global Aviation Safety, Montreal, 2013, p. 22.

83 Brandon Mitchener, Brexit Scenarios for Business Aviation, https://www.gbaa.de/fileadmin/pdf/201801_Brexit_and_Business_Aviation.pdf accessed on May 2019.

84 OECD, "Air Service Agreement Liberalisation and Airline Alliances", International Transport Forum, https://www.itf-oecd.org/sites/default/files/docs/14airserviceagreements.pdf accessed on May 2019.

85 ECC Net, Alternative Dispute Resolution in the Air Passenger Rights, 2012, p. 11.

86 Victor Rodriguez, Cristiana Santos and Pompeu Casanovas, "Ontology-Driven Legal Support-System in the Air Transport Passenger Domain", CEUR, Volume 1296, Issue 2, 2014, pp. 1-10.
} 
breakthrough for this issue. ${ }^{87}$ This kind of restructuration aid may give an opportunity to each of airlines industry in ASEAN to improve their services and quality. ${ }^{88}$ The ASEAN Air Transport Working Group as the authority, which has the responsibility to take care of aviation issue in ASEAN, may formulate and promulgate the subsidy. The subsidy may take different forms, either grants, equity infusions, loans, or loans guarantees. ${ }^{89}$ To achieve common standard of quality among the airlines industry, this restructuration aid should be evaluated continuously. As an illustration, the subsidy may only be granted once in a ten-year period and at the end of period, the airlines industry shall create their progressive report. By this report, the authority may read the progress and see the improvement of quality from all of airlines industry. Therefore, the ASEAN open skies models may be benefited to the all stakeholders, either the consumer, airlines industry or governments and definitely increasing the level of competition between airlines industry.

\section{H. Conclusion}

The intention to establish open skies policy was influenced by the dynamics form of air sovereignty. Liberalization of airspace is a requirement of globalization era for the sake of greater benefits. At the same time, open skies agreement supports the implementation of ASEAN single market policy. On the other hand, state sovereignty has been developed from time to time. At regional level, the sovereignty of every ASEAN member states should be preserved. In addition, it has to confirm the regional aspirations to create open skies policy to maximize the benefits for people. Therefore, an open skies agreement will not revoke state sovereignty. Instead, it may bring mutual advantages at regional framework.

The role of air sovereignty is vital for the establishment of open skies policy. The state parties have already consented to establishing Open Skies policy. In terms of ASEAN open skies policy, every ASEAN member must agree to establish open skies policy. For that reason, the establishment of open skies policy does not trespass member state's sovereignty.

Open skies policy also brings several advantages in many sectors, either direct or indirect. Passengers and Airlines are the main actors who receive direct advantages of open skies policy. Users of air transportation in ASEAN will gain benefit of lower fares if this policy can be implemented. Also, it will influence the

87 Stefan Gossling, Frank Fichert and Peter Forsyth, "Subsidies in Aviation", Sustainability, Volume 9, Issue 8, 2017, pp.1-19

88 P. Beria, H.M Niemeier and K. Frohlich, "Alitalia-the failure of national carrier", Journal of Air Transport Management, Volume 17, Issue 3, 2011, pp. 215-220.

89 WTO (World Trade Organization), World Trade Report 2006 Exploring the Links between Subsidies, Trade and the WTO, 2006. pp. 47-54. 
increase of revenue from ASEAN's tourism sector. In comparison, Single European Sky (SES) has successfully launched its open skies policy. Without a doubt, SES faced many challenges in adoption and implementation of the policy. Nevertheless, currently, SES member states receive many benefits from the policy. In addition, in order to drive ASEAN open skies policy run smoothly, ASEAN member states needs to establish a new international agreement on the implementation of air freedom rights completely.

\section{Reference:}

\section{Books}

Abu Daud Busroh, Ilmu Negara, Bumi Aksara, Jakarta, 1993.

Alford, Eugene, The Impact of the 2007 U.S.-EU Open Skies Air Transport Agreement, U.S Department of Commerce, Washington, 2007.

Bernhardt, R, ed, Encyclopedia of Public International Law Discussion of The Term Sovereignty from Aristotle to Present, North-Holland Publishing Company, New York, 1989.

Brattle Group, The Economic Impact of an EU -US Open Aviation Area The Brattle Group Ltd, London, 2002.

Brierly, J. L, The Law of Nations: An Introduction to the International Law of Peace, 1st ed.Clarendon Press, Gloucestershire, 1928.

Brownlie, Ian, Principles of Public International Law, 6th edition, Oxford University Press, Oxford, 2003.

Chayes, Abram \& Antonia $\mathrm{H}$ Chayes, The New Sovereignty: Compliance with International Regulatory Agreements, Harvard University Press, Cambridge, 1995.

Dempsey, Paul Stephen, Public International Air Law, Mc Gill University, Montreal, 2008.

Diederiks-Verschoor, I. H. Ph, An Introduction to Air Law, Kluwer Law International, The Hague, 1991.

Doganis, Rigas , The Airline Business, Routledge, London, 2006.

Fachri Mahmud, ASEAN Open Sky dan Tantangan bagi Indonesia, PT. Mahmud Yunus Wadzuriyah, Jakarta, 2012.

H. Oum, Dr. Tae, Analysis of Canada's Bilateral Air Services Agreements: Policy Focus on Asia-Pacific Region, The International Institute of Transport \& Logistics (IITL), Victoria, 2008.

Haanappel, Peter P. C, The Law and Policy of Air Space and Outer Space: A Comparative Approach, Kluwer Law International, The Hague, 2003.

Krasner, S, Sovereignty: Organized Hypocrisy, Princeton University Press, Princeton, 1999.

Lachs, Manfred, The Law of Outer Space: An Experience In Contemporary LawMaking, Martinus Nijhoff Publisher, The Netherland, 2010. 
Lee, Dexter, The European and Southeast Asian Single Aviation Markets, European Union Center in Singapore, Singapore, 2015.

McDougal, Myres S. (et. al.), Law and Public Order in Space, Yale University Press, Yale, 1963.

O'Connell, D. P, International Law, 2nd edition, Cambridge University Press, London, 1970.

Salter, Michael \& Mason, Julie, Writing Law Dissertation: An Introduction and Guide to the Conduct of Legal Research, Pearson, Harlow, 2007.

Shaw, Malcolm, International Law, $6^{\text {th }}$ edition, Cambridge University Press London, 2008.

Hamilton, Booz Allen., The Economic Impacts of an Open Aviation Area Between the EU and the US Final Report, Booz Allen Hamilton Ltd, London, 2007.

\section{Other Documents}

Acharya, Amitav, "Culture, Security, Multilateralism: The 'ASEAN Way' and Regional Order" Contemporary Security Policy, Volume 19, Issue 1, 2007.

ASEAN Secretariat, ASEAN Tourism Marketing Strategy 2017-2020, Jakarta, 2017.

Bowen, John T., "Now Everyone can fly? Scheduled airline services to secondary cities in southeast Asia", Journal of Air Transport Management, Volume 53, Issue 1, 2016.

Brandon Mitchener, "Brexit Scenarios for Business Aviation, https://www.gbaa.de/fileadmin/pdf/2018-

01_Brexit_and_Business_Aviation.pdf, accessed on May 2019.

Beria, P., Niemeier, H.M \& Frohlich, K., "Alitalia-the failure of national carrier", Journal of Air Transport Management, Volume 17, Issue 3, 2011.

Cline, Hannah E., "Hijacking Open Skies: The Line Between Tough Competition and Unfair Advantage in the International Aviation Market", Journal of Air Law and Commerce, Vol. 81, Issue.3, 2016.

Cooper, John Cobb., "The Air Navigation Conference, Paris 1910", Journal of Air Law and Commercial, Vol.19, Issues 2, 1952.

Debyser, Ariane., Single European Sky, European Parliamentary Research Service, Strasbourg, 2015.

Deng, Francis M., "From 'Sovereignty as Responsibility' to the 'Responsibility to Protect", Global Responsibility to Protect, Volume 2, Issue 4, 2010.

ECC Net, Alternative Dispute Resolution in the Air Passenger Rights, 2012.

Erotokritou, Chrystel., "Sovereignty Over Airspace: International Law, Current Challenges, and Future Developments for Global Aviation", Inquiries Journal of Social Science, Arts, and Humanities, Volume 4, Issue 5, 2012. 
Eurocontrol, Evaluation of the Impact of the Single European Sky Initiative on ATM Performance, Performance Review Commission upon the invitation of the European Commission DG-TREN, Brussels, 2006.

European Commission, The Single Europeans Sky Fact Sheet, Eurocontrol, Brussels, 2011.

Findlay, Christopher., "The Trans-Tasman Single Aviation Market", Journal of Transport Economics and Policy, Volume 30, Issue 3, 1996.

First Report on the Implementation of the Single Sky Legislation: achievements and the way forward, Commission of the European Communities (CEC), Brussels, 2017.

Forstyh, Peter, (et.al.), "Open Skies in ASEAN", Journal of Air Transport Management, Volume 12, Issue 3, 2006.

Forsyth, Peter., Preparing ASEAN for Open Sky, AADCP Regional Economic Policy Support Facility Research Project 02/008, Monash International Pty Ltd, Australia, 2004.

Frontier Dispute: Benin v. Niger, Judgment, International Court of Justice (ICJ), 2005.

Gossling, Stefan, Fichert, Frank \& Forsyth, Peter, "Subsidies in Aviation", Sustainability, Volume 9, Issue 8, 2017.

Gee, Chuck Y., "Aviation and Tourism: The Travelling Public", Transportation Law Journal, Volume 20, Issue 1, 1991.

Hanaoka, Shinya (et.al), "Low-cost Carriers Versus Full service Carrires in ASEAN: The Impact of Liberalization policy on Competition", Journal of Air Transport Management, Volume 40, Issue 1, 2014.

Hartman \& Boscoianu, "Single European Sky - the transformation of the aviation industry based on the dynamic capabilities", Incas Bulletin, Volume 7, Issue 1, 2015.

Hedlund, Daniel C., "Toward Open Skies: Liberalizing Trade in International Airline Services", Minnesota Journal of Global Trade, Volume 3, Issue 2, 1994.

Hughes, William J., "Aerial Intrusions by Civil Airliner and the Use of Force", Journal of Air and Commerce, Volume 45, Issue 3, 1980.

ICAO, "Manual on the Regulation of International Air Transport", from https://www.icao.int/Meetings/a39/Documents/Provisional_Doc_9626.pdf, accessed on March 25th, 2019.

International Civil Aviation Organization (ICAO), State of Global Aviation Safety, Montreal, 2013.

INTERVISTAS, "The Economic Impacts of Air Service Liberalization 2015", http://www.intervistas.com/wpcontent/uploads/2015/07/The_Economic_Impa cts_of_Air_Liberalization_2015.pdf, accesed on April 2019.

Jennifer Meszaros, "Protectionism Still Winning as Liberalization Stalls", https://www.ainonline.com/aviation-news/air-transport/2016-02-

15/protectionism-still-winning-liberalization-stalls, accessed on February 2019. 
Levine, Michael E., "Airline Competititon in Deregulated Markets: Theory, Firm Strategy, and Public Policy", Yale Journal on Regulation Volume 4, Issue 2, 1987. Lykotrafiti, Antigoni, "Liberalisation of International Civil Aviation: Charting the Legal Flightpath", Elsevier Transport Policy, Volume 43, Issue 1, 2015.

Mott Macdonald, "ASEAN Open Skies Impact Assessment", https://www.mottmac.com/article/3964/asean-open-skies-impact-assessment, accessed on February 2019.

Military and Paramilitary Activities in and Against Nicaragua: Nicaragua Vs U.S., Judgment, 1986.

Nurhendiarni, Sri (et.al.), "The effect of ASEAN Open Skies policy 2015 Upon Opportunities for Low-Cost Carriers in Indonesia - A Case Study of PT.Citilink", The South East Asian Journal of Management SEAM, Volume 9, Issue 1, 2015.

OECD, Air Service Agreement Liberalisation and Airline Alliances, https://www.itfoecd.org/sites/default/files/docs/14airserviceagreements.pdf, accessed on May 2019.

Pitfield, D.E., "The assessment of the EU-US open skies agreement: the counterfactual and other difficulties", Journal of Air Transport Management, Volume 15, Issue 6, 2009.

Rodriguez, (et. al.), “Ontology-Driven Legal Support-System in the Air Transport Passenger Domain", CEUR, Volume 1296, Issue 2, 2014.

Schless, Adam L., "Open Skies: Loosening The Protectionist Grip on International Civil Aviation", Emory International Law Review, Vol.8, Issue 1, 1994.

Silalahi, Sahat Aditua F. \& Wirabrata, Achmad., "Strategi dalam Menghadapi ASEAN Open Sky 2015", Jurnal Ekonomi \& Kebijakan Publik, Volume 4, Issue 1, 2013.

Smyth, Mark \& Pearce, Brian. , Airline Liberalisation: IATA Economics Briefing No. 7, International Air Transport Association, Montreal, 2007.

Stanescu, Daniel, "Single European Sky - The Solution For An Air Traffic Management Adapted To The Challenges of This Century", Review of the Air Force Academy, Vol.33,No.1, 2017.

Tan, Alan Khee-Jin., "The ASEAN Multilateral Agreement on Air Services: En Route to Open Skies?", Journal of Air Transport Management, Vol.16, Issue.6, 2010.

The European Commission, All-Causes Delay to Air Transport in Europe, Brussels, 2017

Towards ASEAN Open Sky, MIDF Research, Malaysia, 2014.

US Department of State, Open Skies Agreement Highlights, https://20012009.state.gov/e/eeb/rls/fs/2006/208.html, accessed on March 23 ${ }^{\text {rd }}, 2019$.

Wassenbergh, H. A., "The Application of International Trade Principles to Air Transport", Air and Space Law, Vol.12, Issue. 2, 1987. 
Wee, Datuk Dr. Victor., Impact of Air Services Liberalisation on Growth of Tourism in Asia, Proceeding $6^{\text {th }}$ UNWTO International Meeting on Silk Road Tourism, Gansu, 1-3 August 2013.

Winnie Yoh, (et. al), "ASEAN on Track for Open Skies Policy", http://www.thejakartapost.com/news/2015/03/19/asean-track-open-skiespolicy.html, accessed on February 12th, 2019.

Winston, Clifford \& Jia Yan, "Open Skies: Estimating Travelers Benefits from Free Trade in Airline Services", American Economic Journal: Economic Policy, Vol. 7, Issue 2, 2015.

Wiradipradja, E. Saefullah, "Open Skies Policy: The Developing Countries Points of view", Jurnal Hukum Internasional, Volume 8, Issue 1, 2010.

Working Paper Conference on The Economics of Airports and Air Navigation Services, International Civil Aviation Organization (ICAO) No. 56, Montreal, 1520 September 2008.

World Travel \& Tourism Council, Travel \& Tourism Economic Impact 2017 South East Asia, 2017.

WTO (World Trade Organization), World Trade Report 2006 Exploring the Links between Subsidies, Trade and the WTO, 2006.

\section{Legal Documents}

Convention on International Civil Aviation, Chicago, 1944.

International Air Services Transit Agreement, Chicago, 1944.

Protocol to amend the Air Transport Agreement between the United States of America and the European Community and its Member States, signed on 25 and 30 April 2007, Entry into Force 2010.

Regulation (EC) No 549/2004 of the European Parliament and of the Council of 10 March 2004 laying down the framework for the creation of the Single European sky.

Regulation (EC) No 550/2004 of the European Parliament and of the Council of 10 March 2004 on the provision of air navigation services in the Single European Sky.

Regulation (EC) No 551/2004 of the European Parliament and of the Council of 10 March 2004 on the organisation and use of airspace in the Single European sky.

Regulation (EC) No 552/2004 of the European Parliament and of the Council of 10 March 2004 on the interoperability of the European Air Traffic Management Network.

The Pan American Convention on Commercial Aviation 1928.

The Single European Sky, European Economic and Social Committee (EESC), 2013.

The U.S.-EU Air Transport Agreement (ATA) of April 302007.

Trans-Tasman Single Aviation Market, ICAO Secretariat July 2017. 